\title{
Ammonia volatilization from arable land after application of cattle slurry. 1. Field estimates
}

\author{
J. VAN DER MOLEN ${ }^{*}$, H. G. VAN FAASSEN 1 , M. Y. LECLERC 2 , \\ R. VRIESEMA ${ }^{1} \&$ W. J. CHARDON 1 \\ 1 Institute for Soil Fertility Research, P.O. Box 30003, NL 9750 RA Haren, Netherlands \\ 2 Utah State University, Department of Soil Science and Biometeorology, Logan, UT \\ 84322, USA
}

Received 25 October 1989; accepted 15 March 1990

\begin{abstract}
Cattle slurry was surface-applied to bare soil in two experiments in the period SeptemberNovember 1987, while in April-May 1988 two experiments were carried out in which the slurry was mixed with the upper $6 \mathrm{~cm}$ of the soil with a cultivator immediately after spreading. The 1987 experiments both lasted 18 days, the 1988 experiments 9 days. A micrometeorological technique, which did not disturb the dynamics of the air flow, was employed for the $\mathrm{NH}_{3}$ volatilization measurements. In addition, volatilization losses were determined indirectly from mineral-N contents of soil/slurry samples collected at intervals after application. Diurnal fluctuations in the $\mathrm{NH}_{3}$ flux occurred throughout the experimental period, with maxima around midday and minima at midnight. The magnitude of the daily flux values decreased with time.

The amounts of $\mathrm{N}$ lost through volatilization from surface-applied cattle slurry were 18 and $33 \%$ of the total $\mathrm{N}$, respectively, during the first 9 days, corresponding to 32 and $67 \%$ of the ammoniacal $\mathrm{N}$ applied with the slurry. Volatilization became negligible after day 9 . Incorporation of the slurry into the soil considerably decreased the loss of $\mathrm{N}$ through volatilization: volatile losses of $\mathrm{N}$ after 9 days amounted to 6 and $7 \%$ of the total $\mathrm{N}$, which corresponds to 11 and $16 \%$ of the ammoniacal $\mathrm{N}$ applied with the slurry.
\end{abstract}

Keywords: ammonia volatilization, field measurement, cattle slurry, arable land, surface application, incorporation

\section{Introduction}

Annual ammonia emissions from animal manures in the Netherlands are estimated to be $250 \times 10^{3} \mathrm{Mg}$; a substantial part of this ammonia may contribute to soil acidification through nitrification after deposition. Ammonia volatilization from manured pasture and arable land is assumed to constitute about $50 \%$ of the total emission. The amount of ammonia volatilized from manured pasture and arable

\footnotetext{
* Present address: TAUW Infra Consult BV, P.O. Box 479, NL 7400 AL Deventer, Netherlands.
} 
land can be reduced by irrigation of the manured surface, by incorporation or injection of the manure into the soil and by lowering the $\mathrm{pH}$ of the manure.

The goal of the present study was to measure ammonia volatilization from arable land under field conditions after surface application or incorporation of cattle slurry. As field experiments in completely or partially closed systems are not truly representative of field conditions because of the lack of a realistic near-surface turbulent flow (Gordon et al., 1988), a micrometeorological technique which did not disturb the dynamics of the air flow was used to measure the rate of ammonia volatilization. In addition, volatilization losses were determined indirectly from mineral- $\mathrm{N}$ content measurements of soil/slurry samples collected at intervals after application. The data obtained from this study will be used for calibration and validation of a transfer model for ammonia volatilization, described by van der Molen et al. (1990).

\section{Materials and methods}

The experiments were done at the experimental farm of the Institute for Soil Fertility Research in Haren, the Netherlands. Circular plots of $21 \mathrm{~m}$ radius were used for the experiments, on a slightly acid sandy soil (Podzol; Table 1). A computerized slurry-spreader was used to register the amount of slurry applied per unit of area every two seconds. Circularity was approximated by spreading $3-\mathrm{m}$ wide strips of decreasing length.

Table 1. Characteristics of cattle slurry and the sandy soil used in the experiments.

\begin{tabular}{|c|c|c|c|c|c|c|c|c|}
\hline & \multicolumn{8}{|l|}{ Cattle slurry } \\
\hline & \multirow{2}{*}{$\begin{array}{l}\text { Date of } \\
\text { application }\end{array}$} & \multirow{2}{*}{$\begin{array}{l}\text { Slurry } \\
\text { application } \\
\left(\mathrm{m}^{3} \mathrm{ha}^{-1}\right)\end{array}$} & \multirow{2}{*}{$\begin{array}{l}\text { Dry } \\
\text { matter } \\
\left(\mathrm{g} \mathrm{kg}^{-1}\right)\end{array}$} & \multirow[t]{2}{*}{$\mathrm{pH}$} & \multicolumn{2}{|c|}{$\mathrm{N}$ analysis } & \multicolumn{2}{|l|}{$\mathrm{N}$ applied } \\
\hline & & & & & $\begin{array}{l}\text { total } \mathrm{N} \\
\left(\mathrm{g} \mathrm{kg}^{-1}\right)\end{array}$ & $\begin{array}{l}\mathrm{NH}_{4}-\mathrm{N} \\
\left(\mathrm{g} \mathrm{kg}^{-1}\right)\end{array}$ & $\begin{array}{l}\text { total N } \\
\left(\mathrm{kg} \mathrm{ha}^{-1}\right)\end{array}$ & $\begin{array}{l}\mathrm{NH}_{4}-\mathrm{N} \\
\left(\mathrm{kg} \mathrm{ha}^{-1}\right)\end{array}$ \\
\hline Exp. 1 & 29-09-'87 & $31^{\mathrm{a}}$ & 96 & 7.3 & 5.6 & 2.8 & 170 & 85 \\
\hline Exp. 2 & 26-10-' 87 & $31^{\mathrm{a}}$ & 94 & 7.5 & 5.0 & 2.7 & 155 & 85 \\
\hline Exp. 3 & $12-04-' 88$ & $30^{\mathrm{b}}$ & 120 & 7.7 & 6.5 & 3.0 & 195 & 90 \\
\hline \multirow[t]{3}{*}{ Exp. 4} & $25-04-' 88$ & $29 b$ & 92 & 7.9 & 6.1 & 3.0 & 180 & 90 \\
\hline & \multicolumn{8}{|c|}{ Soil (1-10 cm layer) } \\
\hline & $\begin{array}{l}\text { Organic C } \\
(\%)\end{array}$ & $\begin{array}{l}\text { Total N } \\
(\%)\end{array}$ & $\begin{array}{l}\text { CEC } \\
\text { (meq } 100 \mathrm{~g}\end{array}$ & & $\begin{array}{l}\text { pH } 1: 2.5 \\
1 \mathrm{M} \mathrm{KC} 1\end{array}$ & & & \\
\hline Exp. 1 & 2.1 & 0.17 & 11 & & 5.6 & & & \\
\hline Exp. 2 & 1.7 & 0.13 & 8.6 & & 5.0 & & & \\
\hline Exp. 3 & 2.1 & 0.17 & 11 & & 5.6 & & & \\
\hline Exp. 4 & 1.7 & 0.13 & 8.6 & & 5.0 & & & \\
\hline
\end{tabular}

a Surface-applied.

b Incorporated. 


\section{Flux calculations}

The experiments described in this paper were originally designed to employ the 'Integrated Horizontal Flux' (IHF) method (Ryden \& McNeill, 1984), in which the rate of $\mathrm{NH}_{3}$ volatilization is basically calculated from the exact shapes of wind velocity and $\mathrm{NH}_{3}$ concentration profiles. However, during the flux calculations the IHF method was found to be strongly limited by uncertainties in the exact shape of the $\mathrm{NH}_{3}$ concentration profiles, especially near the soil surface, which were obtained from measured $\mathrm{NH}_{3}$ concentrations at six heights only. Therefore, later a 'Theoretical Profile Shape' (TPS) method was used to avoid the uncertain extrapolations in the shape of the $\mathrm{NH}_{3}$ concentration profiles of the IHF-method.

In the TPS method a micrometeorological model was used to calculate the rate of volatilization of $\mathrm{NH}_{3}$ to the atmosphere. This model was first developed by Beauchamp et al. (1978), theoretically explained by Wilson et al. (1982) and tested experimentally by Wilson et al. (1983). This micrometeorological model was subsequently improved by Brunke et al. (1988) to incorporate the horizontal velocity fluctuations (which are important in the case of small plots) and to make the plume three-dimensional (also important in small plots).

The reader is referred to the papers above for a detailed account of the technique. Here, it should suffice to say that the $\mathrm{NH}_{3}$ molecules being emitted from a manured plot (i.e. the vertical $\mathrm{NH}_{3}$ flux will be advected horizontally by the mean wind and can thus be 'counted' through a vertical plane at some distance from their origin (the horizontal $\mathrm{NH}_{3}$ flux). The model reproduces individual trajectories of $\mathrm{NH}_{3}$ molecules leaving the surface patch and gives these molecules a mean wind speed proportional to their current height. In addition, it gives the molecules instantaneous velocities analogous to those found outdoors (i.e. with the gusts). The model inputs are source strength, wind profile and surface roughness. The model predicts a vertical concentration profile at different distances downwind from the source. The model accounts for the effect of atmospheric stability through the velocity profile and through the turbulent velocities and length scales used as input (this indicates the mean size of the eddies in which the $\mathrm{NH}_{3}$ molecules are transported, which changes with time of day). Thus, the surface source strength in the field can be deduced from measurements of mean wind speed and mean $\mathrm{NH}_{3}$ concentrations as follows:

$$
F=\frac{[\bar{u} \bar{c}]_{\text {measured }}}{\left[\frac{\overline{u c}}{F}\right]_{\text {TPS model }}}
$$

where:

$F=$ volatilization rate $\left(\mu \mathrm{g} \mathrm{m}^{-2} \mathrm{~s}^{-1}\right)$

$\bar{u}=$ mean wind speed $\left(\mathrm{m} \mathrm{s}^{-1}\right)$, at a certain height (ZINST)

$\bar{u} \bar{c}=$ mean $\mathrm{NH}_{3}-\mathrm{N}$ concentration $\left(\mu \mathrm{g} \mathrm{m}^{-3}\right)$, at a certain height (ZINST)

$\overline{u c}=$ mean product of instantaneous wind speed and concentration at height ZINST. 
At height ZINST Equation 1 holds, regardless of atmospheric stability. Wind speed and $\mathrm{NH}_{3}$ concentration at height ZINST were estimated from the measured profiles.

\section{Micrometeorological flux measurements}

In order to apply the micrometeorological technique, a mast was placed at the centre of the circular plot with $\mathrm{NH}_{3}$ samplers at heights of $0.37,0.87,1.63,2.11,3.07$ and $4.30 \mathrm{~m}$ above the surface. A background $\mathrm{NH}_{3}$ concentration was measured periodically at another mast at the windward side of the plot, with $\mathrm{NH}_{3}$ samplers at heights of $0.37,0.87,1.63,2.11$ and $3.07 \mathrm{~m}$. Outside the circular plots, a mast was positioned at which wind velocities were recorded at $0.20,0.35,0.65,1.20,2.20$, 4.25 and $6.50 \mathrm{~m}$ above the surface. Wind direction was recorded at the top of this mast $(7.50 \mathrm{~m})$.

Wind velocities were measured with Casella cup anemometers (T16108/2) at the lowest three positions, while at the four top positions Lambrecht cup anemometers (1469I) were used. The velocity thresholds of the anemometers were 0.16 and 0.20 $\mathrm{m} \mathrm{s}^{-1}$, respectively. Wind direction was measured with a Wittich \& Visser wind vane (PRP). A schematic representation of the experimental set-up is given in Figure 1.

Wind velocities and wind direction were recorded by a datalog system (Datataker DT 100F), from which hourly-averaged values of wind velocity and a frequency table (in min $\mathrm{h}^{-1}$ ) of wind direction were calculated. A record of wind direction is particularly important since the $\mathrm{NH}_{3}$ background concentration can be overestimated due to a shift in wind direction causing the windward mast to be contaminated by flow from the experimental plot. Data were transferred to a portable PC (Compaq III TM) and stored on floppy disk.

To collect $\mathrm{NH}_{3}$ at the different heights, air from each height was drawn through

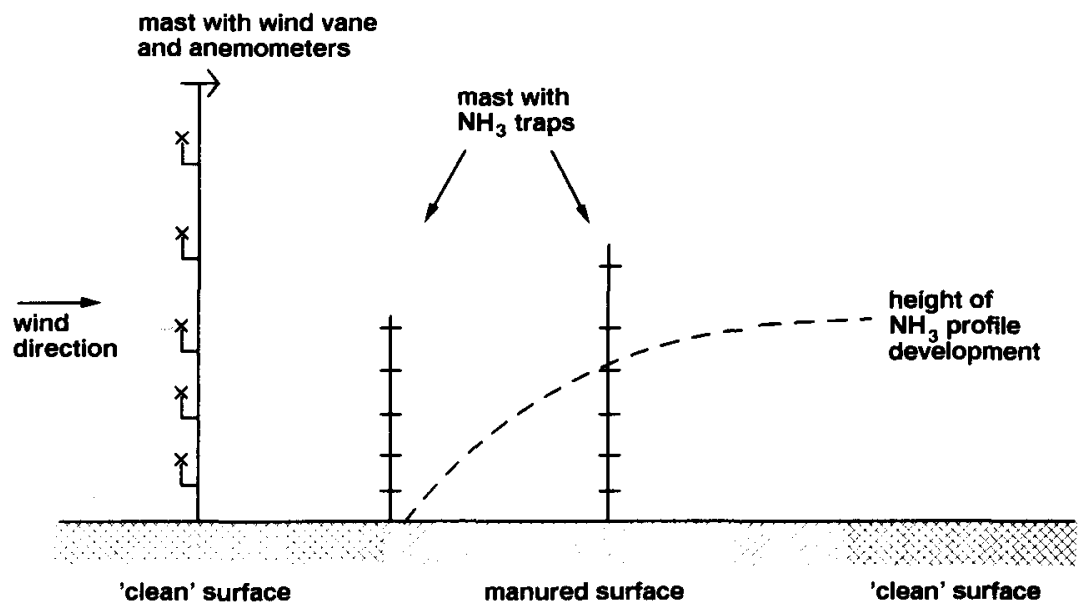

Fig. 1. Schematic representation of the experimental set-up. 
a separate trap containing $20 \mathrm{ml}$ of $0.02 \mathrm{M} \mathrm{H}_{3} \mathrm{PO}_{4}$ at a rate of $1201 \mathrm{~h}^{-1}$. Each trap consisted of a $100-\mathrm{cm}^{3}$ test tube with ground glass neck (Quickfit MF 24/3/8) fitted with a Drechsel bottle head (Quickfit MF27/3/13) supporting a gas dispersion tube with a mean pore diameter of $40-90 \mu \mathrm{m}$. Tests with this type of trap showed virtually complete absorption of ammonia. The traps were connected to a Charles Austin membrane pump (A85.S/E) by means of $50.0 \mathrm{~m}$ soft PVC tubing (diameter $6 \mathrm{~mm}$ ), a condensation reservoir and Gapon (GT) flowmeter. Condensation reservoirs, flowmeters, pumps and datalog system were positioned in a mobile unit which was placed outside the field. The $\mathrm{NH}_{3}$ content in the trap solution was determined according to NEN 6472 (1983) using a PYE UNICAM spectrophotometer (SP6-300).

\section{Soil mineral-N balance}

The amounts of mineral $\mathrm{N}$ in the slurry and in the soil after application will change as a result of several competing processes (Fig. 2: 1a-3b, and 5).

Losses of mineral $\mathrm{N}$ to the atmosphere can occur by volatilization of $\mathrm{NH}_{3}$ (4) and by denitrification of nitrate $(3 a / b)$, while losses to deeper soil layers can occur by leaching of nitrate (5). Several processes interconvert organic and mineral-N pools: mineralization (1a-1c), immobilization (1d/e), turnover (1f/g) (MIT) and nitrification $(2 \mathrm{a} / \mathrm{b})$. Mineral- $\mathrm{N}$ balance calculations should take into account all processes where either mineral $\mathrm{N}$ is lost or formed. As a first approximation the amount of organic $\mathrm{N}$ is assumed to be constant, i.e. no net $\mathrm{N}$ mineralization or net immobilization occurs over periods of days (van Faassen \& van Dijk, 1986). Leach-

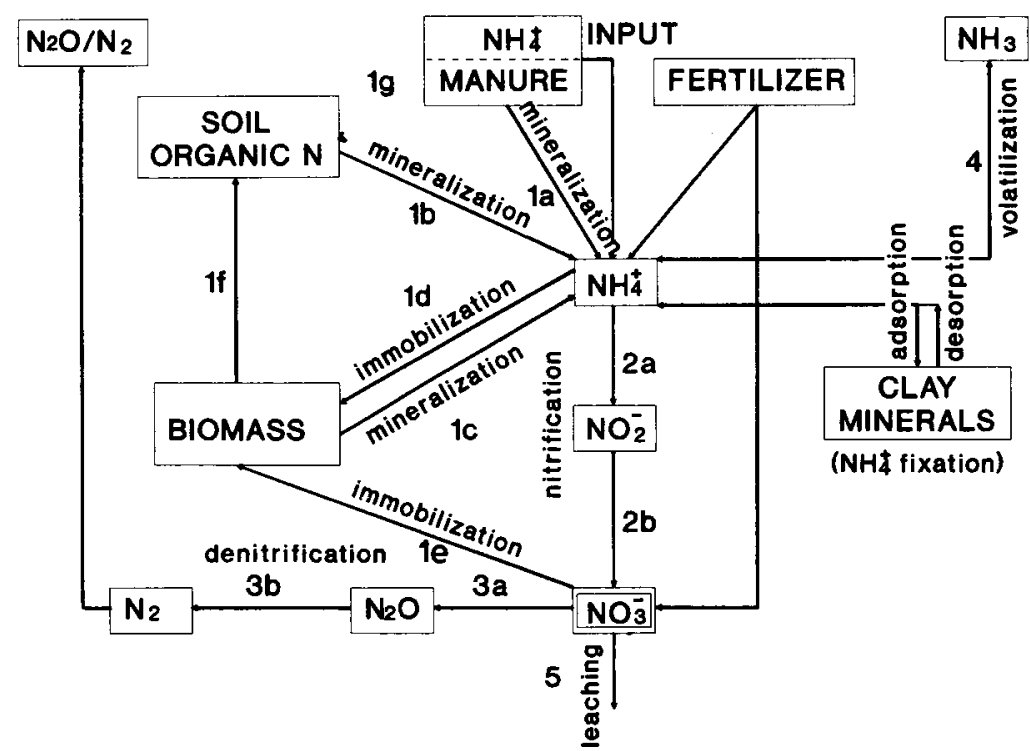

Fig. 2. Processes that affect the amounts of mineral $\mathrm{N}$ in the soil/slurry system (adapted from van Veen, 1977). 
ing depends on rainfall and can be estimated from results of analyses of several (deeper) soil layers for mineral N. In the sandy soil of the experimental site irreversible fixation of $\mathrm{NH}_{4}+$ by specific clay minerals could be expected to be negligible. Under conditions where no leaching occurs, decreases in $\mathrm{NO}_{3}-\mathrm{N}$ content are indicative of denitrification. Slurry application is known to promote denitrification, especially when it is incorporated into the soil.

The total amount of mineral $\mathrm{N}$ present immediately after slurry application, Nmin slurry + Nmin soil, was compared with mineral $\mathbf{N}$ recovered in soil samples at different times after slurry application. $\mathrm{NH}_{3}$ volatilization was estimated, from the part of mineral $\mathrm{N}$ that was not recovered, taking into account nitrification, denitrification and leaching.

Samples from the layer $0-5 \mathrm{~cm}$ were taken as cylinders with a surface area of 20 $\mathrm{cm}^{2}$. Samples from the layers $0-10$ and $10-20 \mathrm{~cm}$ were taken with a soil auger and represented about $10 \mathrm{~cm}^{2}$ each. Ten samples per layer were combined to one mixed sample for analysis. Samples were weighed to determine volumetric mass, which was used to convert concentrations of mineral $\mathrm{N}$ into $\mathrm{kg} \mathrm{ha}^{-1}$. For auger samples of the layers $10-20,20-40$ and $40-60 \mathrm{~cm}$, average volumetric masses were used of 1200 , 1400 and $1600 \mathrm{~kg} \mathrm{~m}^{-3}$, respectively. In some cases, separate samples were taken from the soil in the wheel tracks and the soil in-between the tracks. Tracks covered about $50 \%$ of the surface area in these experiments. Dry matter contents were determined by oven-drying of subsamples at $105^{\circ} \mathrm{C}$ overnight. Mineral-N contents were determined by analysing $1 \mathrm{M} \mathrm{KCl}$ extracts of the samples for ammonium and nitrate with a Technicon autoanalyser (Traacs 800).

\section{Additional measurements}

Additional measurements were carried out to supply input for the transfer model, mentioned in the introduction. Global radiation, relative humidity and temperature were measured at $1.5 \mathrm{~m}$ height using a Kipp solarimeter (CM 11) and a Rotronic humidity and temperature sensor (RH 100). Thermistors (Uni-Curve, UUA 33J1) were used to measure the air temperature at $0.02 \mathrm{~m}$ above the soil surface and the soil temperature at 6 different places in the plot at $0.02 \mathrm{~m}$ below the surface. The data obtained were registered by the datalog system mentioned above. Rainfall was recorded mechanically by a Van Doorn rainfall gage (70038/9). Global radiation, relative humidity, air temperature, soil temperature and rainfall data were averaged to hourly values.

The $\mathrm{pH}$ and the volumetric moisture content were determined once or twice a day. The $\mathrm{pH}$ values and volumetric moisture contents presented in this paper are averages of five determinations made throughout the experimental plot each time. The volumetric moisture content was determined gravimetrically $(0-5 \mathrm{~cm})$. In order to measure the $\mathrm{pH}$ in the field, the surface of the soil-slurry mixture was moistened with distilled water and a flat-surface combination glass electrode (Sensorex $450 \mathrm{C}$ ) was placed on it. In the case of surface-applied slurry the $\mathrm{pH}$ was measured at the surface only, while in the case of incorporated slurry additional $\mathrm{pH}$ values were determined at $0.05 \mathrm{~m}$ depth. 


\section{Experimental program}

Cattle slurry was surface-applied to bare soil in two experiments in the period September-November 1987, while in April-May 1988 two experiments were carried out in which the slurry was mixed with the upper $0.06 \mathrm{~m}$ of the soil with a cultivator immediately after spreading. More information on the experiments is given in Table 1 .

Experiments 1 and 2 lasted 18 days, while Experiments 3 and 4 lasted 9 days. In Experiments 1 and 2 the $\mathrm{NH}_{3}$ traps were changed at 2-hourly intervals in the daytime and at 3-hourly intervals at night. Because incorporation of the slurry decreased the magnitude of the $\mathrm{NH}_{3}$ fluxes, longer intervals were used in Experiments 3 and 4: two 3-hourly intervals in the daytime, and a third interval was taken from 4 p.m. to 8 a.m. the next day. For the periods between the measuring intervals the flux was estimated by interpolation.

\section{Results and discussion}

$\mathrm{NH}_{3}$ fluxes estimated by the micrometeorological technique are shown in Figure 3. The time at which the slurry was applied is indicated by a vertical arrow. In Experiments 1 and 2, volatilization became negligible after day 9 .

Estimated cumulative $\mathrm{NH}_{3}-\mathrm{N}$ losses at the end of day 9 were 57, 27, 14 and 10 $\mathrm{kg} \mathrm{ha}^{-1}$, respectively. However, it should be noted that because of the limited size of the experimental plots, edge effects including horizontal advection of $\mathrm{NH}_{3}$ by the mean wind may no longer be negligible. The estimated rates of $\mathrm{NH}_{3}$ volatilization, and so the estimated cumulative $\mathrm{NH}_{3}-\mathrm{N}$ losses, may therefore be fetchdependent.

In agreement with Beauchamp et al. (1982), who also used a micrometeorological method to determine the rate of $\mathrm{NH}_{3}$ volatilization from surface-applied cattle slurry, a diurnal pattern in the volatilization rate was observed, with maxima around midday and minima in the early morning. The magnitude of the daily flux values decreased with time.

Measured $\mathrm{pH}$ values as a function of time are given in Figure 4, in which the $\mathrm{pH}$ values of the cattle slurry before application have been taken as the initial $\mathrm{pH}$ values.

To compare the environmental conditions during the four experiments, daily averages are given in Table 2 for a number of weather and soil variables. The first day was the day on which the slurry was spread. For many variables, hourly data were collected which will be used in a further paper on model validation to explain the observed $\mathrm{NH}_{3}$ fluxes.

\section{$\mathrm{NH}_{3}$ loss from surface-applied vs. incorporated slurry}

In the case of surface-applied slurry, $\mathrm{pNH}_{3}$ was much higher than with incorporated slurry, because about six times as much $\mathrm{NH}_{4}-\mathrm{N}$ was present in the top $\mathrm{cm}$ of the soil and the $\mathrm{pH}$ at the soil surface was also higher (Fig. 4). As the difference in 
J. VAN DER MOLEN ET AL.
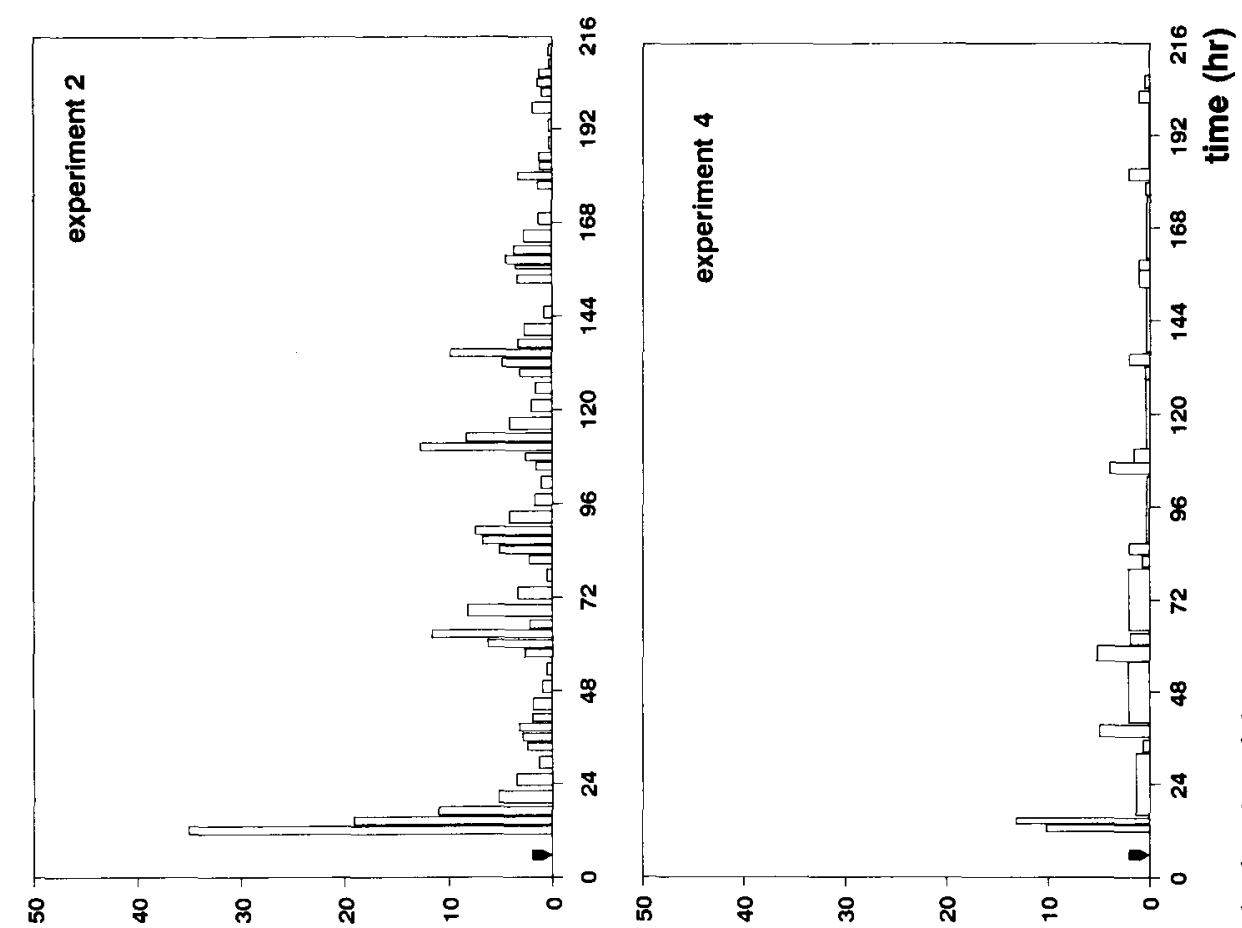

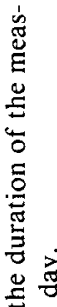

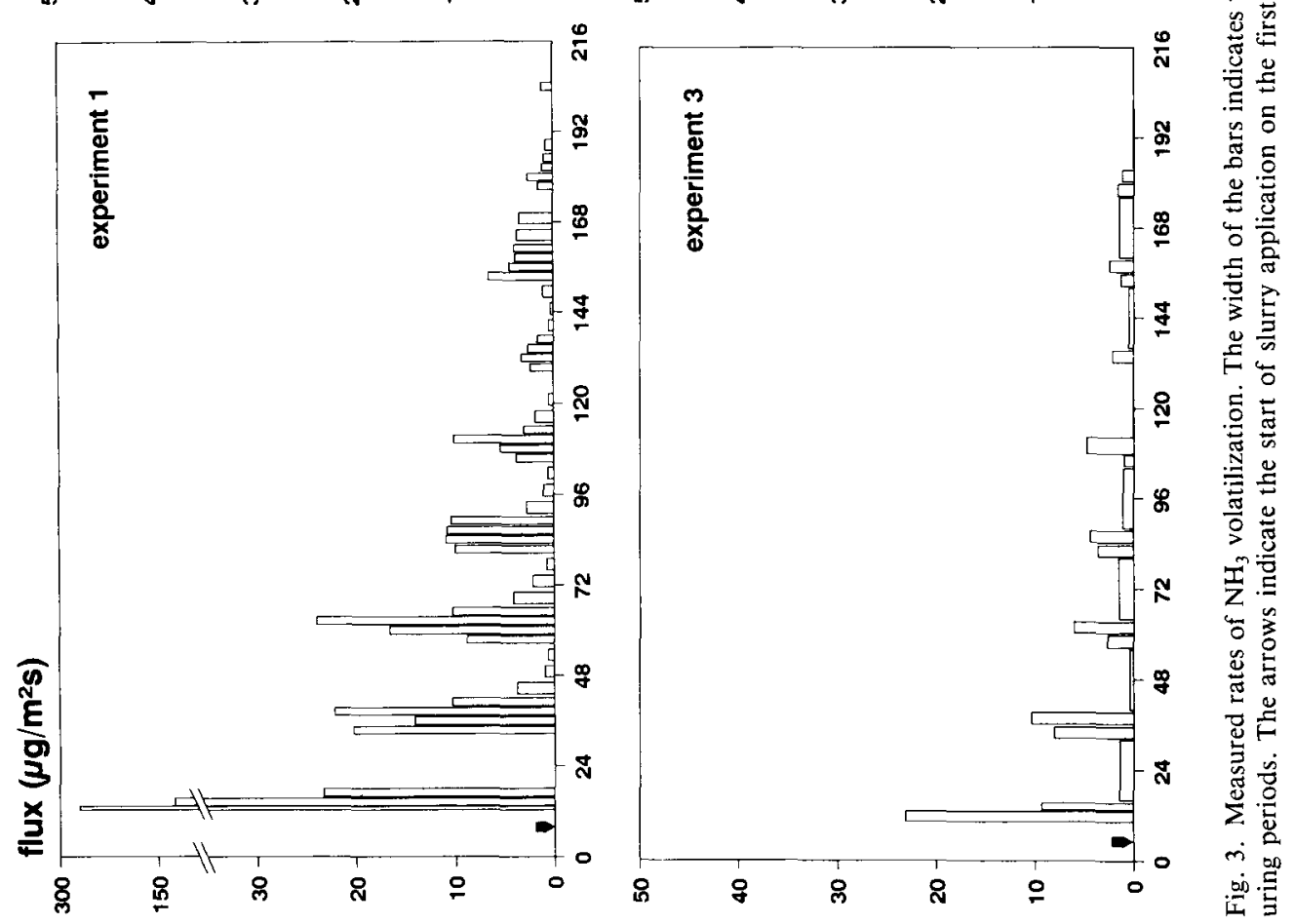




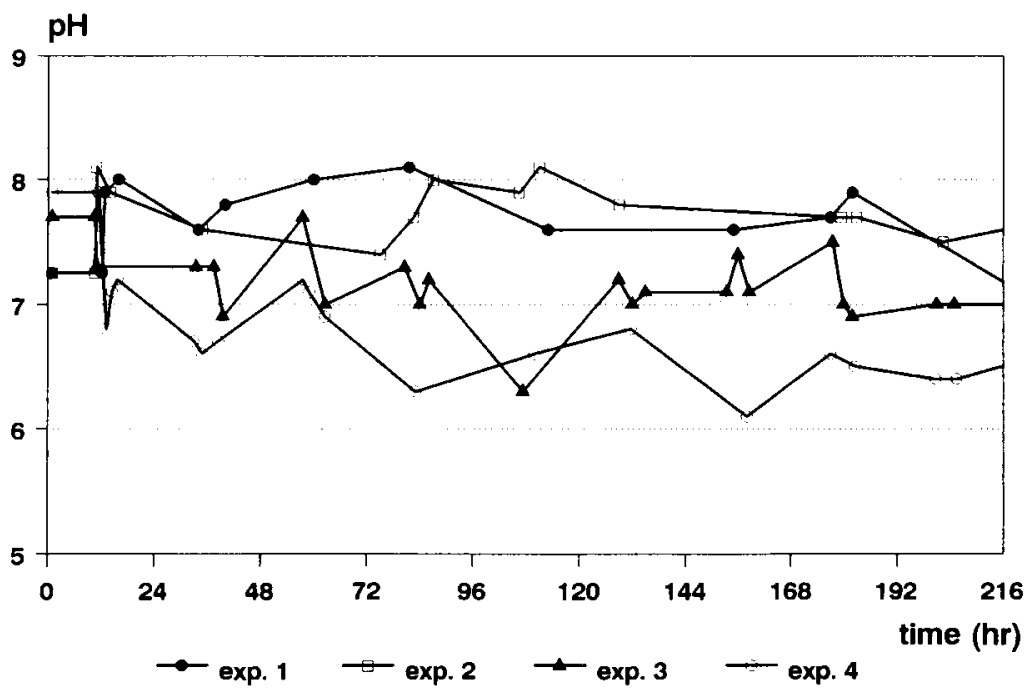

Fig. 4. Measured $\mathrm{pH}$ values as a function of time.

$\mathrm{pNH}_{3}$ between the soil surface and the atmosphere is the driving force for $\mathrm{NH}_{3}$ volatilization, this largely explains why $\mathrm{NH}_{3}$ losses were higher from surfaceapplied than from incorporated slurry. Differences in other factors that promote $\mathrm{NH}_{3}$ volatilization, such as high wind speed and drying conditions (high temperatures, low relative humidity and high radiation), further account for observed differences in $\mathrm{NH}_{3}$ losses (Table 2).

$\mathrm{NH}_{3}$ loss from surface-applied slurry

During the first four days the $\mathrm{NH}_{3}$ flux in Experiment 1 was clearly higher than that in Experiment 2 (Fig. 3). This may be due to the higher global radiation, higher soil temperature (days 1 and 2), higher surface $\mathrm{pH}$, higher wind speed and lower humidity in Exp. 1 than in Exp. 2 (Table 2). Although the volumetric moisture content of the $0-5 \mathrm{~cm}$ soil layer was higher in Exp. 1 than in Exp. 2, for the top $\mathrm{cm}$ the reverse may have been true. Crust formation by more rapid drying in Exp. 1 must have prevented drying out of the $1-5 \mathrm{~cm}$ layer. The heavy loss of $\mathrm{NH}_{3}$ during days 1-4 in Exp. 1 eventually must have compensated for the factors that promoted volatilization more strongly than in Exp. 2, resulting in almost equal $\mathrm{NH}_{3}$ fluxes from day 5 onwards.

In Experiments 1 and 2, volatilization became negligible after day 9, either due to lack of $\mathrm{NH}_{4}-\mathrm{N}$ (Exp. 1; Table 3) or because of nitrification (Exp. 2; Fig. 5). Background $\mathrm{NH}_{3}$ concentrations generally were about $10 \mu \mathrm{g}$ of $\mathrm{N}$ per $\mathrm{m}^{3}$ air. Most of the background concentrations were measured during the day. When the wind direction changed during a measuring period, increased background concentrations were often measured when the wind had blown over the manured field to the back- 
J. VAN DER MOLEN ET AL.

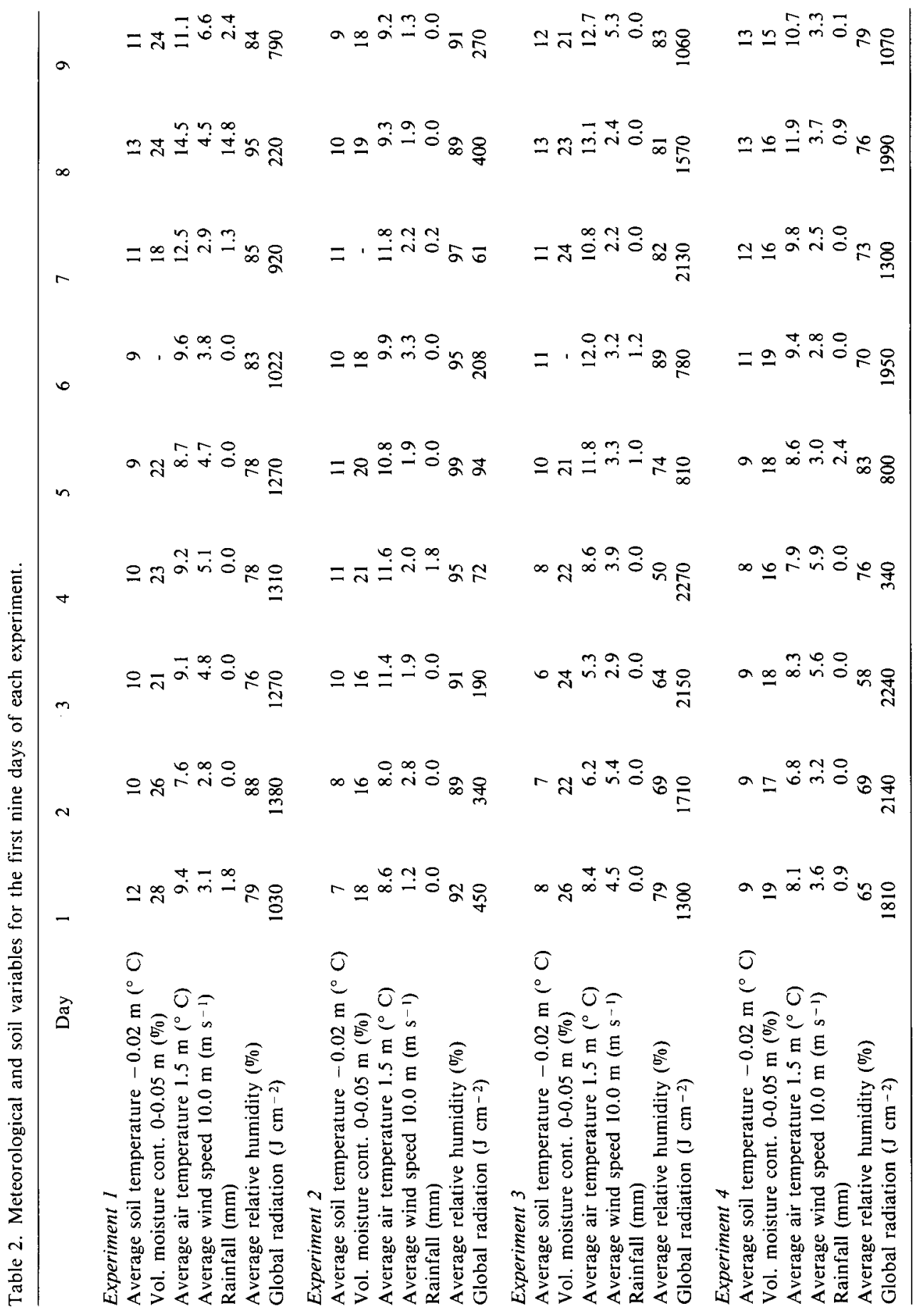


Table 3. Calculated mineral- $\mathrm{N}$ balance based on soil sampling (Exp. 1).

\begin{tabular}{llccc}
\hline Soil layer $(\mathrm{cm})$ & Time & $\mathrm{NH}_{4}-\mathrm{N}+\mathrm{NO}_{3}-\mathrm{N}=$ mineral-N (kg ha-1) \\
$0-20$ & day-0 & 0 & 32 & 32 \\
$0-5$ & $1 \mathrm{~h}$ & 53 & 1 & 54 \\
$0-5$ & $2 \mathrm{~h}$ & 73 & 1 & 74 \\
$0-10$ & & & & \\
$10-20$ & 7 days & 6 & 19 & 25 \\
$0-20$ (sum) & 7 days & $<0.4$ & 18 & 18 \\
\hline
\end{tabular}

ground mast. In such cases the real background concentration was estimated from the concentration at the highest measurement point on the central mast.

$\mathrm{NH}_{3}$ loss from soil-incorporated slurry

Overall $\mathrm{NH}_{3}$ volatilization in Experiments 3 and 4 was similar; this can be expected because, on average, environmental conditions were about the same (Table 2).

Soil mineral-N balance

In Experiment 1 the calculated $\mathrm{NH}_{4}-\mathrm{N}$ loss from the $0-20 \mathrm{~cm}$ layer after 7 days was

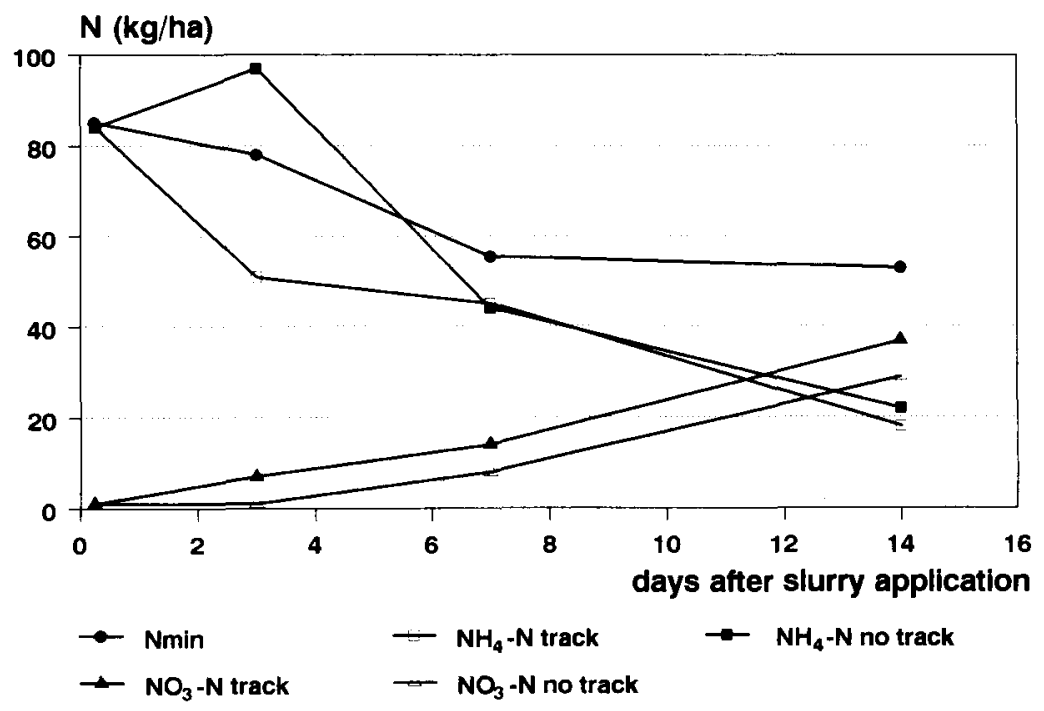

Fig. 5. Mineral $\mathrm{N}$ in the $0-5 \mathrm{~cm}$ layer (Exp. 2). 
$74 \mathrm{~kg} \mathrm{ha}^{-1}$ by $\mathrm{NH}_{3}$ volatilization and $5 \mathrm{~kg} \mathrm{ha}^{-1}$ by nitrification. After 27 days the calculated mineral-N loss from the $0-60 \mathrm{~cm}$ layers was $90 \mathrm{~kg} \mathrm{ha}^{-1}$, of which 23 was by denitrification and/or leaching, and 67 by $\mathrm{NH}_{3}$ volatilization (Table 3).

In Experiment 2 the calculated $\mathrm{NH}_{4}-\mathrm{N}$ loss from the $0-5 \mathrm{~cm}$ layer after 7 days was $31 \mathrm{~kg} \mathrm{ha}^{-1}$ by $\mathrm{NH}_{3}$ volatilization and $10 \mathrm{~kg} \mathrm{ha}^{-1}$ by nitrification. After 14 days the calculated $\mathrm{NH}_{4}-\mathrm{N}$ loss was $33 \mathrm{~kg} \mathrm{ha}^{-1}$ by $\mathrm{NH}_{3}$ volatilization and $32 \mathrm{~kg}$ ha ${ }^{-1}$ by nitrification. The decrease in $\mathrm{NH}_{4}-\mathrm{N}$ between days 7 and 14 equaled the increase in $\mathrm{NO}_{3}-\mathrm{N}$, which explains why no $\mathrm{NH}_{3}$ volatilization was measurable during that period. Nitrification seemed to have started earlier in the wheel tracks than between the wheel tracks (Fig. 5); $\mathrm{NH}_{3}$ volatilization from these two positions
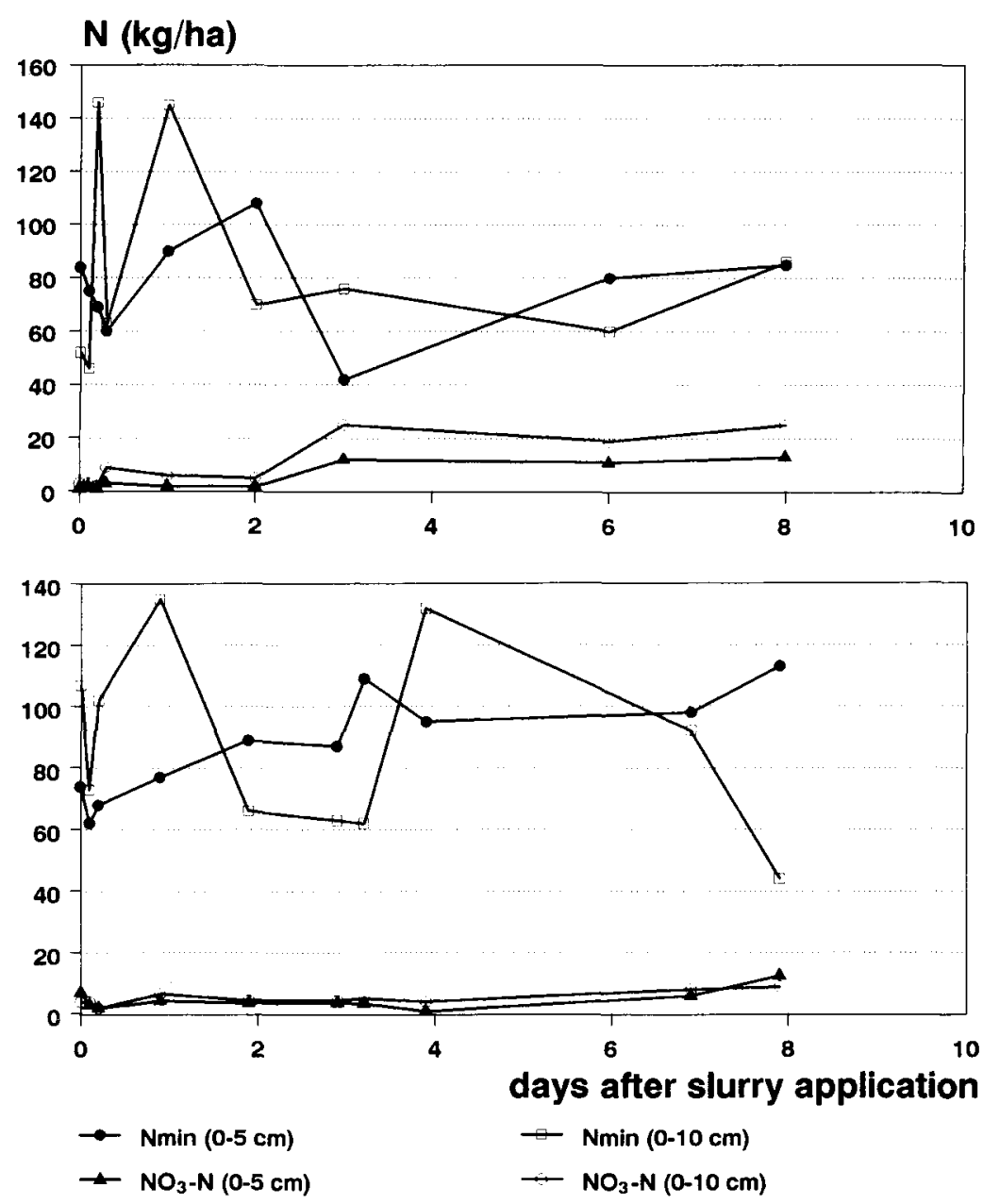

Fig. 6. Mineral $\mathrm{N}$ and $\mathrm{NO}_{3}-\mathrm{N}$ in the $0-5$ and $0-10 \mathrm{~cm}$ layer in Exp. 3 (top) and Exp. 4 (bottom). 
must have been different too, because of differences in soil physical properties (e.g. surface roughness, bulk density).

In Experiments 3 and 4, soil mineral- $\mathrm{N}$ content varied widely in both the $0-5$ and 0-10 cm layers, reflecting an uneven distribution of the slurry applied (Fig. 6). Thus it was almost impossible to estimate $\mathrm{NH}_{4}-\mathrm{N}$ losses from soil analyses. Nitrification was not very rapid during the first week, leaving sufficient $\mathrm{NH}_{4}-\mathrm{N}$ for $\mathrm{NH}_{3}$ volatilization to continue after day 9 at the low rate measured during days 6 to 9 (Fig. 3).

\section{Summary and conclusions}

The measured amounts of $\mathrm{N}$ lost through volatilization from surface-applied cattle slurry were 18 (Exp. 2) and $33 \%$ (Exp. 1) of the total N, respectively, corresponding to 32 (Exp. 2) and $67 \%$ (Exp. 1) of the ammoniacal $\mathrm{N}$ applied with the slurry. This difference may be accounted for by the higher global radiation, higher soil temperature (days 1 and 2), higher surface $\mathrm{pH}$, higher wind speed and lower humidity in Exp. 1 than in Exp. 2. Diurnal fluctuations in the $\mathrm{NH}_{3}$ flux occurred throughout the experimental period, with maxima around midday and minima at midnight. In both experiments, volatilization became negligible after day 9, either due to lack of $\mathrm{NH}_{4}-\mathrm{N}$ (Exp. 1) or because of nitrification (Exp. 2).

Incorporation of slurry (Experiments 3 and 4) considerably decreased the loss of $\mathrm{N}$ through volatilization: measured volatile losses of $\mathrm{N}$ amounted to 6-7 \% of the total $\mathrm{N}$, that is $11-16 \%$ of the ammoniacal $\mathrm{N}$ applied with the slurry. The relatively small difference in $\mathrm{NH}_{3}$ volatilization in these experiments can be explained by the fact that, on average, environmental conditions were similar. The difference in overall $\mathrm{NH}_{3}$ volatilization between Experiments 1-2 and 3-4 can be explained by the fact that in the case of surface application $\mathrm{pNH}_{3}$ was much higher than with incorporated slurry, about 6 times more $\mathrm{NH}_{4}-\mathrm{N}$ being present in the top $\mathrm{cm}$ of the soil and the $\mathrm{pH}$ at the soil surface also being higher.

In Experiment 1 the calculated $\mathrm{NH}_{4}-\mathrm{N}$ loss from the $0-20 \mathrm{~cm}$ layer after 7 days was $74 \mathrm{~kg} \mathrm{ha}^{-1}$ by $\mathrm{NH}_{3}$ volatilization and $5 \mathrm{~kg} \mathrm{ha}^{-1}$ by nitrification. In Experiment 2 the calculated $\mathrm{NH}_{4}-\mathrm{N}$ loss from the $0-5 \mathrm{~cm}$ layer after 7 days was $31 \mathrm{~kg}$ ha-1 by $\mathrm{NH}_{3}$ volatilization and $10 \mathrm{~kg} \mathrm{ha}^{-1}$ by nitrification. In Experiments 3 and 4 , soil mineral-N content varied widely in both the $0-5$ and $0-10 \mathrm{~cm}$ layers, reflecting an uneven distribution of the slurry applied. Thus it was almost impossible to estimate $\mathrm{NH}_{4}-\mathrm{N}$ losses from soil analyses in Experiments 3 and 4. Nitrification was rather slow during the first week, leaving sufficient $\mathrm{NH}_{4}-\mathrm{N}$ for $\mathrm{NH}_{3}$ volatilization to continue after day 9 at the low rate measured during days 6 to 9 .

\section{Acknowledgements}

Part of the project was financed by the Dutch Priority Programme on Acidification. The authors acknowledge the assistance of Mr G. Bezu. 


\section{J. VAN DER MOLEN ET AL.}

\section{References}

Beauchamp, E. G., G. E. Kidd \& G. W. Thurtell, 1978. Ammonia volatilization from sewage sludge applied in the field. Journal of Environmental Quality 7: 141-146.

Beauchamp, E. G., G. E. Kidd \& G. W. Thurtell, 1982. Ammonia volatilization from liquid dairy cattle manure in the field. Canadian Journal of Soil Science 62: 11-19.

Brunke, R., P. Alvo, P. Schuepp \& R. Gordon, 1988. Effect of meteorological parameters on ammonia loss from manure in the field. Journal of Environmental Quality 17: 431-436.

Faassen, H. G. van \& H. van Dijk, 1987. Manure as a source of nitrogen and phosphorus in soils. In: Meer, H. G. van der, R. J. Unwin, T. A. van Dijk \& G. C. Ennik (Eds), Animal Manure on Grassland Soil and Fodder Crops, p. 27-45. Martinus Nijhoff, Dordrecht.

Molen, J. van der, A. C. M. Beljaars, W. J. Chardon, W. A. Jury \& H. G. van Faassen, 1990. Ammonia volatilization from arable land after application of cattle slurry. 2. Derivation of a transfer model. Netherlands Journal of Agricultural Science 38 (in press).

Gordon, R. M., M. Y. Leclerc, P. Schuepp \& R. Brunke, 1988. Field estimates of ammonia volatilization from swine manure by a simple micrometeorological technique. Canadian Journal of Soil Science 68: 369-380.

NEN 6472, 1983. Water - Photometric determination of ammonium content, 1983. Dutch Normalization Institute.

Ryden, J. C. \& J. E. McNeill, 1984. Application of the micrometeorological mass balance method to the determination of ammonia loss from a grazed sward. Journal of the Science of Food and Agriculture 35: 1297-1310.

Veen, J. A. van, 1977. The behaviour of nitrogen in soil; a computer simulation model. Ph.D.-thesis, Free University of Amsterdam, $164 \mathrm{pp}$.

Wilson, J. D., G. W. Thurtell, G. E. Kidd \& E. G. Beauchamp, 1982. Estimation of the rate of gaseous mass transfer from a surface source plot to the atmosphere. Atmospheric Environment 16: 1861-1867.

Wilson, J. D., V. R. Catchpoole, O. T. Denmead \& G. W. Thurtell, 1983. Verification of a simple micrometeorological model for estimating the rate of gaseous mass transfer from the ground to the atmosphere. Agricultural Meteorology 29: 183-189. 